\title{
STRATEGI MEMBENTUK KARAKTER SEMANGAT KEBANGSAAN ANGGOTA AMBALAN KYAI MOJO DAN NYI AGENG SERANG
}

\section{Erik Aditia Ismaya ${ }^{1}$ dan Farid Noor Romadlon ${ }^{2}$}

${ }^{1}$ Prodi Pendidikan Guru Sekolah Dasar, ${ }^{2}$ Prodi Pendidikan Bahasa Inggris, Fakultas Keguruan dan Ilmu Pendidikan Universitas Muria Kudus, Indonesia

\section{Info Artikel}

Sejarah Artikel:

Diterima Maret 2017

Disetujui Mei 2017

Dipublikasikan Juni 2017

Keywords: character, spirit of nationality, scout

\begin{abstract}
The purpose of this study is to analyze the strategy of character formation of national spirit of Ambalan Kyai Mojo and Nyi Ageng Serang members based in MA Nahdhlotul Muslimin Undaan Kudus. This research uses qualitative approach with field study method and descriptive research type. Data collection using observation and interview method. Data validity using source triangulation techniques and data were analyzed using Miles-Huberman interactive model. The results showed that in order to form the character of the national spirit of scout members Ambalan Kyai Mojo and Nyi Ageng Serang, the strategy pursued is by holding a regular exercise. There is also a Scout Work Unit (SAKA) exercise to educate and train members according to their interests. Members of Ambalan Kyai Mojo and Nyi Ageng Serang are members of SAKA Bhayangkara (Police), SAKA Pandu Wisata (Culture and Tourism Service), SAKA Wana Bakti (Perhutani) and SAKA Wira Kartika (KODIM). The spirit of nationality continues to grow and develop in the soul of every member of the scout Ambalan Kyai Mojo and Nyi Ageng Serang when inducted into Bantara Enforcer. Not all members of Ambalan Kyai Mojo and Nyi Ageng Serang can pass and escaped and be sworn in to Bantara Enforcers because of the rigorous and tough exam must be taken. Tri Satya is the sacred promise of every Bantara Enforcer when inaugurated by the coach. Tri Satya and Dasa Darma spirit is what makes every Enforcer Bantara Ambalan Kyai Mojo and Nyi Ageng Serang become a patriot plenary.
\end{abstract}

\section{Abstrak}

Tujuan penelitian ini yaitu menganalisis strategi pembentukan karakter semangat kebangsaan anggota Ambalan Kyai Mojo dan Nyi Ageng Serang berpangkalan di MA Nahdhlotul Muslimin Undaan Kudus. Penelitian ini menggunakan pendekatan kualitatif dengan metode studi lapangan dan tipe penelitian deskriptif. Pengumpulan data menggunakan metode observasi dan wawancara. Validitas data menggunakan teknik triangulasi sumber dan data dianalisis menggunakan model interaktif Miles-Huberman. Hasil penelitian menunjukkan bahwa dalam rangka membentuk karakter semangat kebangsaan anggota pramuka Ambalan Kyai Mojo dan Nyi Ageng Serang, strategi yang ditempuh yaitu dengan mengadakan latihan rutin. Ada pula latihan Satuan Karya Pramuka (SAKA) untuk mendidik dan melatih anggotanya sesuai minat. Anggota Ambalan Kyai Mojo dan Nyi Ageng Serang ada yang menjadi anggota SAKA Bhayangkara (Kepolisian), SAKA Pandu Wisata (Dinas Kebudayaan dan Pariwisata), SAKA Wana Bakti (Perhutani) dan SAKA Wira Kartika (KODIM). Semangat kebangsaan terus tumbuh dan berkembang dalam jiwa setiap anggota pramuka Ambalan Kyai Mojo dan Nyi Ageng Serang ketika dilantik menjadi Penegak Bantara. Tidak semua anggota Ambalan Kyai Mojo dan Nyi Ageng Serang bisa lulus dan lolos serta dilantik menjadi Penegak Bantara karena ujian yang ketat dan berat harus ditempuh. Tri Satya merupakan janji suci setiap Penegak Bantara ketika dilantik oleh pembina. Semangat Tri Satya dan Dasa Darma inilah yang menjadikan setiap Penegak Bantara Ambalan Kyai Mojo dan Nyi Ageng Serang menjadi seorang patriot paripurna.

(C) 2017 Universitas Muria Kudus 


\section{PENDAHULUAN}

Indonesia sebagai bangsa yang plural dan multikultur merupakan sebuah kenyataan yang tidak terbantahkan sejak sebelum kemerdekaan. Oleh karena itu, ketika Negara Kesatuan Republik Indonesia merdeka pada tanggal 17 Agustus 1945, para pendiri bangsa sepakat menerima Pancasila dengan semboyan Bhinneka Tunggal Ika sebagai dasar negara.

Para pendiri bangsa sangat menyadari realitas bangsa yang plural dan multikultur. Oleh karena itu, untuk mewujudkan Indonesia yang merdeka, bersatu, berdaulat, adil dan makmur, para pendiri bangsa rela mengorbankan kepentingan pribadi dan kelompok demi kepentingan bangsa dan negara. Jika pada waktu itu para pendiri bangsa tidak berhati lapang, berjiwa besar serta rela berkorban demi bangsa dan negara, maka bukan Pancasila yang menjadi dasar negara, karena ada Piagam Jakarta yang secara khusus mengakomodasi kepentingan umat Islam sebagai mayoritas masyarakat Indonesia.

Pancasila merupakan bukti dari semangat kebangsaan para pendiri bangsa. Untuk itu, Pancasila harus menjadi pedoman hidup setiap warga negara Indonesia. Namun di era reformasi dan globalisasi saat ini, muncul sebuah fenomena yang memprihatinkan pada semangat kebangsaan masyarakat dan bangsa Indonesia.

Sejak era reformasi bergulir pada tahun 1998 dan terbukanya arus informasi global, Pancasila terkesan tidak lagi dijadikan "rujukan utama" (main literature) dalam kehidupan bermasyarakat, berbangsa, dan bernegara, sehingga lunturlah semangat kebangsaan masyarakat dan bangsa Indonesia, khususnya para generasi mudanya. Perilaku generasi muda (pemuda) Indonesia yang terjebak dalam pergaulan bebas, aktivitas pornografi, pornoaksi, serta ancaman dan jebakan penyalahgunaan narkoba, Human Trafficking, serta HIV/AIDS sangatlah mengkhawatirkan.

Hal yang lebih memprihatinkan yaitu lunturnya semangat kebangsaan pemuda Indonesia dengan ditolaknya Pancasila sebagai ideologi negara. Ansyaad Mbay (Ketua Badan Nasional Penanggulangan Terorisme) menjelaskan bahwa, dari hasil penelitian yang dilakukan LIPI terhadap perkembangan radikalisme di dunia kampus, terdapat $80,6 \%$ mahasiswa yang menolak Pancasila sebagai ideologi bangsa (Harian Rakyat Merdeka Edisi 19 September 2012).

Penolakan Pancasila sebagai ideologi negara merupakan pukulan untuk bangsa dan negara Indonesia. Nasib serta masa depan bangsa dan negara Indonesia yang ada ditangan pemuda, mulai dipertanyakan keberlanjutannya. Bagaimana mungkin bangsa dan negara Indonesia tetap ada, jika semangat kebangsaan pemuda Indonesia telah luntur dan menolak Pancasila sebagai ideologi negara.

Lunturnya semangat kebangsaan pemuda Indonesia merupakan persoalan bangsa yang serius, mengkhawatirkan dan mendesak untuk segera dicarikan solusi. Jika dibiarkan begitu saja, dipastikan nasib bangsa dan negara Indonesia di masa depan akan suram, dan tidak menutup kemungkinan bahwa Indonesia hanya tinggal kenangan.

Salah satu solusi untuk mengatasi lunturnya semangat kebangsaan pemuda Indonesia yaitu dengan mendorong pemuda Indonesia untuk mengikuti ekstra kurikuler pramuka. Gerakan Pramuka merupakan satusatunya organisasi kepanduan yang sah dan diakui negara dengan ditetapkannya Undangundang Nomor 12 Tahun 2010 Tentang Gerakan Pramuka (UU No 12 Tahun 2010) sebagai dasar hukum Gerakan Pramuka.

Gerakan Pramuka sebagai wadah pendidikan dan pelatihan kepramukaan mempunyai peran dalam pembentukan karakter Pemuda Indonesia. Gerakan Pramuka memberikan bekal kepada pemuda Indonesia supaya memiliki pengendalian diri dan kecakapan hidup untuk menghadapi tantangan dan tuntutan perubahan kehidupan lokal, nasional, dan global. Gerakan Pramuka memiliki tingkatan pendidikan dan pelatihan yang terdiri dari Siaga, Penggalang, Penegak dan Pandega. Pendidikan dan pelatihan pada tingkat Penegak merupakan sebuah "Kawah Candradhimuka" yang sebernarnya bagi para pramuka.

Pramuka penegak di-didik dan dilatih untuk menghadapi kehidupan yang sebenarnya, yaitu hidup bermasyarakat, berbangsa dan bernegara. Melalui sebuah wadah yang bernama ambalan, para pramuka Penegak belajar dan berlatih mengelola sebuah miniatur masyarakat, sehingga setelah para Penegak lulus dari sekolah, mereka telah memiliki ilmu dan kecakapan yang cukup untuk menghadapi kehidupan nyata serta mampu menerapkan ilmu dan kecakapan yang dimilikinya untuk turut serta membangun masyarakat.

Berdasarkan uraian latar belakang, penelitian ini mengungkap strategi pendidikan dan pelatihan anggota pramuka Ambalan Kyai Mojo dan Nyi Ageng Serang berpangkalan di MA Nahdhlotul Muslimin Undaan Kudus sehingga setiap anggota memiliki karakter semangat kebangsaan. 


\section{METODE PENELITIAN}

Penelitian ini menggunakan pendekatan kualitatif dengan metode studi lapangan dan tipe penelitian deskriptif. Lokasi penelitian di MA Nahdhotul Muslimin Undaan Kudus. Data utama diperoleh langsung melalui pengamatan pada kegiatan latihan rutin pramuka dan wawancara dengan Mustarom, S.Ag. (Pembina Pramuka MA Nahdlhotul Muslimin), Azmur Rosyadul Ula (Pradana Amalan Kyai Mojo) dan Sri Rahayu (Pradana Ambalan Nyi Ageng Serang).

Data sekunder diperoleh dari UndangUndang Nomor 12 Tahun 2010 Tentang Gerakan Pramuka, Anggaran Dasar dan Anggran Rumah Tangga Gerakan Pramuka, Buku Syarat Kecakapan Umum, buku kelengkapan administrasi dan dokumen Adat Ambalan Kyai Mojo dan Nyi Ageng Serang, Prosiding seminar nasional "Merajut Generasi Emas Indonesia 2045", Prosiding "Konferensi Pendidikan Anak Usia Dini dan Pendidikan Dasar Sekolah Pascasarjana UPI", dan Skripsi berjudul "Konstribusi Kegiatan Ekstrakuriuler Kepramukaan pada Pembelajaran Geografi di MA Nahdlatul Muslimin Tahun Ajaran 2010/2011”.

Validitas data menggunakan teknik triangulasi sumber dan analisis data yang digunakan adalah model interaktif MilesHuberman.

\section{HASIL DAN PEMBAHASAN}

Upaya membentuk karakter semangat kebangsaan anggota Ambalan Kyai Mojo dan Nyi Ageng Serang, Mustarom selaku pembina pramuka MA Nahdlatul Muslimin Undaan Kudus, menuturkan. Sistem Among, Metode Kepramukaan dan Prinsip Dasar Kepramukaan menjadi pedoman dalam mendidik dan melatih anggota pramuka. Latihan rutin dilaksanakan dua minggu sekali dengan memberikan materimateri kepramukaan maupun non kepramukaan (misalnya fotografi).

Dewan Ambalan melaksanakan kegiatan di alam terbuka selama dua hari untuk menggembleng kekuatan mental dan ketahanan fisik para calon Penegak Bantara. Kegiatan di alam terbuka merupakan salah satu ujian yang harus ditempuh para calon Penegak Bantara. Para calon Penegak Bantara yang lulus dan lolos dalam ujian, layak dilantik sebagai Penegak Bantara setelah menyelesaikan syarat kecakapan umum.

Berdasarkan pengamatan peneliti, siswa anggota pramuka, memiliki sikap yang lebih sopan dibanding siswa lain serta termotivasi untuk berprestasi dibidang akademik maupun non akademik. Berkaitan dengan karakter para anggota pramuka, maka adat ambalan secara khusus mengarahkan para anggota supaya memiliki jiwa Pancasila serta nasionalisme yang tinggi.

Penuturan Mustarom mengenai proses pendidikan dan pelatihan anggota pramuka di Ambalan Kyai Mojo dan Nyi Ageng Serang, diperkuat oleh Azmur Rosyadul Ula selaku Pradana Ambalan Kyai Mojo. Ula menjelaskan bahwa latihan rutin merupakan strategi utama dalam mendidik dan melatih para anggota ambalan. Semua kegiatan pendidikan dan pelatihan anggota ambalan bernafaskan Adat Ambalan, sehingga setiap anggota memiliki karakter khas.

Pada proses pendidikan dan pelatihan pramuka di Ambalan Kyai Mojo dan Nyi Ageng Serang, tidak semua anggota pramuka calon Penegak Bantara dapat dilantik menjadi Penegak Bantara. Hanya calon Penegak Bantara dinyatakan lulus dan lolos dalam ujian syarat kecakapan umum, ujian fisik dan mental, barulah calon Penegak Bantara dapat dilantik menjadi Penegak Bantara.

Pelantikan calon Penegak Bantara menjadi Penegak Bantara dilakukan oleh pembina ambalan dalam sebuah upacara pelantikan. Proses pelantikan ditandai dengan pengucapan Tri Satya oleh pembina dan diikuti oleh para calon Penegak Bantara sebagai janji setia seorang pramuka untuk taat kepada Tuhan YME, Negara Kesatuan Republik Indonesia serta mengamalkan Pancasila, peduli kepada sesama dan menepati Dasa Darma Pramuka. Semangat Tri Satya inilah yang membuat setiap Penegak Bantara Ambalan Kyai Mojo dan Nyi Ageng Serang menjadi seorang patriot paripurna.

Penegak Bantara merupakan panutan bagi para calon Penegak Bantara. Seorang Penegak Bantara merupakan seorang yang berkarakter. Berdasarkan arti dan makna logo pada Ambalan Kyai Mojo dan Nyi Ageng Serang yang dikutip dari lampiran Surat Keputusan Ka. Mabigus Nomor: 18 GP/Gudep MA-NM/KS/142/IV/2002 Tentang Pengukuhan Logo Ambalan Kyai Mojo-Nyi Ageng Serang MA Nahdlatul Muslimin Undaan Kudus, maka karakter seorang anggota pramuka Ambalan Kyai Mojo-Nyi Ageng Serang adalah berjiwa Pancasila, memiliki semangat juang dan berdakwah, cinta alam dan lingkungan sekitar, pantang menyerah, solidaritas dan setia kawan, serta beriman dan berilmu.

Penegak Bantara Kyai Mojo dan Ambalan Nyi Ageng Serang memiliki kewajiban untuk mengembangkan diri dengan 
bergabung pada organisasi dan kegiatan lain diluar pangkalan. Sri Rahayu selaku Pradana Ambalan menjelaskan Penegak Bantara bisa mengembangkan diri sesuai minat dan bakat dengan mengikuti latihan SAKA (Satuan Karya Pramuka), Unit Bantuan dan Pertolongan Pramuka (UBALOKA), Pramuka Peduli atau SAR. Anggota Ambalan Kyai Mojo dan Nyi Ageng Serang ada yang mengikuti SAKA Bhayangkara (Kepolisian), SAKA Pandu Wisata (Dinas Kebudayaan dan Pariwisata), SAKA Wana Bakti (Perhutani) dan SAKA Wira Kartika (KODIM).

Berdasarkan data lapangan, maka strategi pembentukan karakter semangat kebangsaan yang dilakukan Ambalan Kyai Mojo dan Nyi Ageng Serang, dapat digambarkan sebagai berikut.

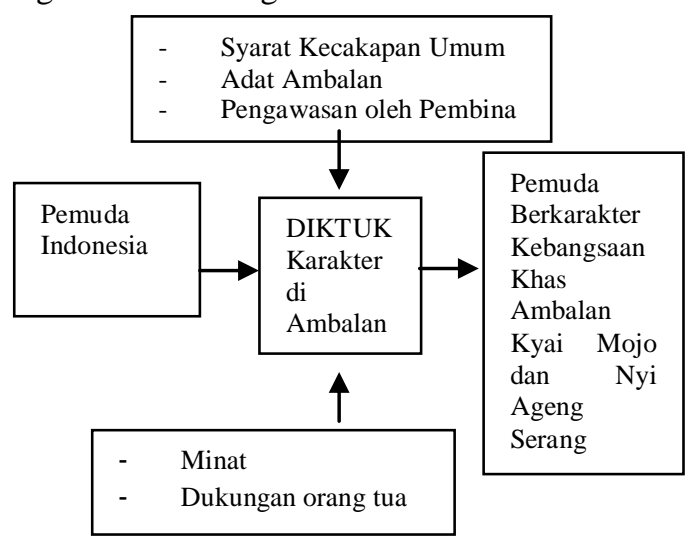

Gambar 1. Model pendidikan dan pembentukan karakter semangat kebangsaan di Ambalan Kyai Mojo dan Nyi Ageng Serang

(Romadlon dan Ismaya 2015)

Gerakan Pramuka sebagai wadah pendidikan dan pelatihan kepramukaan mempunyai peran dalam pembentukan karakter generasi muda Indonesia. Ambalan Kyai MojoNyi Ageng Serang sebagai bagian dari Gerakan Pramuka memiliki cara tersendiri dalam upaya turut serta membentuk pemuda Indonesia, sehingga memiliki karakter semangat kebangsaan.

Semangat kebangsaan merupakan salah satu aspek yang ada dalam 18 nilai karakter yang menjadi acuan pembentukan karakter. 18 karakter tersebut yaitu: religius, jujur, toleransi, disiplin, kerja keras, kreatif, mandiri, demokratis, rasa ingin tahu, semangat kebangsaan, cinta tanah air, menghargai prestasi, bersahabat/komunikatif, cinta damai, gemar membaca, peduli lingkungan, peduli sosial, dan tanggung jawab. Karakter semangat kebangsaan merupakan salah satu sikap yang diharapkan dimiliki oleh setiap Pemuda Indonesia.

\section{SIMPULAN}

Kenyataan bahwa sebagian Pemuda Indonesia menolak Pancasila sebagai dasar negara adalah pukulan telak bagi masyarakat dan bangsa Indonesia. Ambalan Kyai Mojo-Nyi Ageng Serang merupakan salah satu pihak yang tampil dan turut serta dalam mengawal pembentukan karakter semangat kebangsaan dengan caranya sendiri. Oleh karena itu, pembentukan karakter semangat kebangsaan perlu mendapat perhatian segenap pihak, dan yang dilakukan Ambalan Kyai Mojo dan Nyi Ageng Serang perlu diteladani oleh segenap pihak yang peduli akan masa depan bangsa Indonesia.

\section{DAFTAR PUSTAKA}

Buku Syarat Kecakapan Umum Tahun 2009.

Ismaya, Erik Aditia. 2012. Mencetak Generasi Emas Yang Bermental dan Berkepribadian Baik Melalui Pendidikan Kepramukaan di Ambalan JodhipatiCandrasari. Prosiding Seminar Nasional "Merajut Generasi Emas Indonesia", Sabtu 15 September 2012 di Universitas Muria Kudus. Kudus: Badan Penerbit Universitas Muria Kudus.

Ismaya, Erik Aditia. 2013. Gerakan Pramuka Sebagai Center of Youth Leadership Training dalam Upaya Menyongsong Generasi Emas Indonesia 2045. Prosiding Konferensi Nasional Pendidikan Anak Usia Dini dan Pendidikan Dasar Tahun 2013. Sekolah Pascasarjana Universitas Pendidikan Indonesia Bandung. 22-23 November 2013.

Keputusan Kwartir Nasional Gerakan Pramuka Nomor: 203 Tahun 2009 Tentang Anggaran Rumah Tangga Gerakan Pramuka.

Keputusan Presiden Republik Indonesia Nomor 24 Tahun 2009 Tentang Pengesahan Anggaran Dasar Gerakan Pramuka.

Kwarnas. 2009. Anggaran Dasar dan Anggaran Rumah Tangga Gerakan Pramuka. Jakarta: Kwarnas Gerakan Pramuka. 
Miles, M.B. \& Huberman, M.A. 1992. Analisis Data Kualitatif. Terjemahan Rohidi,T.R. Jakarta: Penerbit UI.

Moleong, Lexy J. 2002. Metode Penelitian Kualitatif. Bandung: Remaja Rosdakarya.

Reading, Hugo F. 1986. Kamus Ilmu-ilmu Sosial. Jakarta: Rajawali.

Romadlon, F.N dan Ismaya, E.A. 2015. Education Model and Formation of Indonesia Youth Character Through Scout Movement. Prosiding Conference On Education and Social Science
(ICESS) Faculty of Social Sciences, Semarang State University (UNNES), On May 13, 2015

Tim Penyusun. 2008. Kamus Bahasa Indonesia. Jakarta: Pusat Bahasa.

Undang-undang Republik Indonesia Nomor 12 Tahun 2010 Tentang Gerakan Pramuka. Diunduh pada tanggal 07 Maret 2011 dari www.pramuka.or.id.

Undang-undang Republik Indonesia Nomor 40 Tahun 2009 Tentang Kepemudaan 